\title{
Criminologie
}

\section{Evaluation and Meta-Evaluation of the Effectiveness of Victim-Oriented Legal Reform in Europe}

\section{Marion Brienen, Ernestine Hoegen et Marc Groenhuijsen}

Volume 33, numéro 1, printemps 2000

La victimologie : quelques enjeux

URI : https://id.erudit.org/iderudit/004710ar

DOI : https://doi.org/10.7202/004710ar

Aller au sommaire du numéro

Éditeur(s)

Les Presses de l'Université de Montréal

ISSN

0316-0041 (imprimé)

1492-1367 (numérique)

Découvrir la revue

Citer cet article

Brienen, M., Hoegen, E. \& Groenhuijsen, M. (2000). Evaluation and Meta-Evaluation of the Effectiveness of Victim-Oriented Legal Reform in Europe. Criminologie, 33(1), 121-144. https://doi.org/10.7202/004710ar
Résumé de l'article

La Déclaration de principes fondamentaux de justice relatifs aux victimes de la criminalité et aux victimes d'abus de pouvoir, adoptee par les Nations Unies en 1985, et la Recommandation (85) 11 du Conseil de l'Europe sur le statut des victimes dans le systeme de justice criminel sont des documents importants qui reflètent un consensus internationa concernant les droits des victimes.

'inspirant de cette Déclaration, plusieurs juridictions européennes ont introduit ou amélioré des dispositions relatives aux droits des victimes. Cependant, souvent, ces dispositions ne sont pas actualisées comme prévu, ou resten inopérantes. Pour pallier ce problème, les Nations Unies ont adopté une résolution et rédigé un manuel explicitant les moyens qui en facilitent l'application effective. De plus, certaines juridictions ont compris les difficultes inhérentes à ce type de dispositions. Par exemple, la Hollande a mis la nouvelle Loi sur les victimes en vigueur sur une base connaissances ainsi obtenues au moment de la généralisation de la loi dans le reste du pays.

Des instruments plus sophistiqués sont nécessaires à la définition de paramètres d'application des droits au niveau supranational. Afin de mieux comprendre la situation, nous avons mené une etude comparative de nature empirique juridique dans 22 pays membres du Conseil de l'Europe. L'étude révéla, inter alia, des facteurs de réussite et d'échec. Les effets de ces facteurs sur l'application de la Recommandation (85) 11 sont mis en évidence par des exemples tirés de la rèalité que lon retrouve dans certaines juridictions. Les exemples sont regroupés en quatre thèmes majeurs : information, dédommagement, traitement et protection des victimes.

Selon la deuxième proposition de la Recommandation (85) 11, il est essentiel d'attribuer à la police la responsabilité 'ormelle d'informer les victimes de la possibilite d'obtenir de l'aide, de l'assistance juridique et une indemnisation. Cependant, la moitie des juridictions n'ont pas introduit cette reforme. Notre etude revele que parmi les facteurs d'échec on peut compter une conceptualisation généralisée de la victime comme prétendue victime, et l'attribution de la tâche d'information aux instances judiciaires plutôt qu'à la police. Dans les juridictions où la responsabilitès d'informer existe en tant que fonction formelle, la possibilité d'échec est surtout liée au fait que la police ne s'acquitte de cette tâche que de façon symbolique. Parmi les facteurs favorisant l'application de ces nouvelles dispositions, il y a la mise en place d'incitatifs au plan organisationnel, lelaboration de systemes de contrôle, et la réference systematique des victimes à des services sociaux, d'appui, de conseil et d'assistance juridique. Pour améliorer la transmission des informations, on devrait prévoir des fonds pour financer ce type d'activités, qu'elles soient menées par la police ou pa

En ce qui concerne le dédommagement, la recherche démontre que l'ordonnance de dédommagement, surtout le modèle anglais, est plus efficace que le modele partie civile ou la mesure de dédommagement hollandaise. Le principa facteur de reussite de lordonnance de dédommagement est qu elle est une mesure penale imposẻe par l'État. Cela veut dire que la responsabilité civile n'est pas un prérequis et que la Cour peut ordonner le dédommagement qu'elle considere approprié en tenant compte du statut financier de linculpe. De plus, la Cour est obligée de considérer la possibilité d'emettre l'ordonnance de dédommagement, et d' expliquer pourquoi elle n' est pas imposée. Un facteur déchec dans le cas du modele partie civile cest quil comporte une "clause devasion" s. les reclamations peuvent être

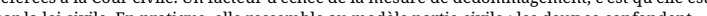

La manière dont les instances judiciaires traitent les victimes peut être améliorée en leur fournissant une formation visant à les conscientiser aux besoins des victimes. Donner cette formation aux nouvelles recrues seulement serait un facteur dechec, car elle ne peut être efficace que si elle est offerte à lensemble du personnel. Offrir des cours de recyclage et en mest que Les facteurs de réussite en ce qui concerne l'interrogatoire des victimes reposent sur une formation spécifique et la mise en place d'installations spéciales : par exemple, salles d'entrevue pour les enfants, salles d'attente pour les victimes de crimes sexuels, enregistrement audiovisuel avant le procès, et interrogatoires à distance par moyens vidéo.

Un moyen fréquent de protéger les victimes est de mener le procès, ou du moins une partie du procès, à huis clos. Le fait que les instances judiciaires s'opposent (fortement) a cette façon de faire représente un facteur d'échec. Créer une obligation formelle pour la Cour de mener tous les procès impliquant des crimes de nature sexuelle à huis clos serait un

Nous concluons que le succès des réformes axées sur les victimes dépend, inter alia, de la clarté et de la précision de telles réformes, de l'absence de " clauses d'evasion ", de l'attitude des décideurs du système pénal, et de la possibilite que ces réformes puis- sent être bénéfiques au contrevenant et (ou) au système pénal dans son ensemble.
Ce document est protégé par la loi sur le droit d'auteur. L’utilisation des services d’Érudit (y compris la reproduction) est assujettie à sa politique d'utilisation que vous pouvez consulter en ligne.

https://apropos.erudit.org/fr/usagers/politique-dutilisation/ 


\section{Evaluation and Meta-Evaluation of the Effectiveness of Victim- Oriented Legal Reform in Europe}

\author{
Marion Brienen \\ Researcher \\ Research and Documentation Centre \\ Ministry of Justice - The Netherlands \\ mbrienen@best-dep.minjus.nl
}

\author{
Marc Groenhuijsen \\ Professor in Criminal Law and Criminal Procedure \\ Tilburg University - The Netherlands \\ m.s.groenhuijsen@kub.nl
}

\section{Ernestine Hoegen}

Trainee-Judge

District Court of Arnhem - The Netherlands

e.h.hoegen@kub.nl

RÉSUMÉ - La Déclaration de principes fondamentaux de justice relatifs aux victimes de la criminalité et aux victimes d'abus de pouvoir, adoptée par les Nations Unies en 1985, et la Recommandation (85) 11 du Conseil de l'Europe sur le statut des victimes dans le système de justice criminel sont des documents importants qui reflètent un consensus international concernant les droits des victimes.

S'inspirant de cette Déclaration, plusieurs juridictions européennes ont introduit ou amélioré des dispositions relatives aux droits des victimes. Cependant, souvent, ces dispositions ne sont pas actualisées comme prévu, ou restent inopérantes. Pour pallier ce problème, les Nations Unies ont adopté une résolution et rédigé un manuel explicitant les moyens qui en facilitent l'application effective. De plus, certaines juridictions ont compris les difficultés inhérentes à ce type de dispositions. Par exemple, la Hollande a mis la nouvelle Loi sur les victimes en vigueur sur une base expérimentale dans deux juridictions afin d'évaluer les effets des nouvelles dispositions et d'appliquer les connaissances ainsi obtenues au moment de la généralisation de la loi dans le reste du pays.

Des instruments plus sophistiqués sont nécessaires à la définition de paramètres d'application des droits au niveau supranational. Afin de mieux comprendre la situation, nous avons mené une étude comparative de nature empirique et juridique dans 22 pays membres du Conseil de l'Europe. L'étude révéla, inter alia, des facteurs de réussite et 
d'échec. Les effets de ces facteurs sur l'application de la Recommandation (85) 11 sont mis en évidence par des exemples tirés de la réalité que l'on retrouve dans certaines juridictions. Les exemples sont regroupés en quatre thèmes majeurs : information, dédommagement, traitement et protection des victimes.

Selon la deuxième proposition de la Recommandation (85) 11, il est essentiel d'attribuer à la police la responsabilité formelle d'informer les victimes de la possibilité $\mathrm{d}^{\prime}$ obtenir de l'aide, de l'assistance juridique et une indemnisation. Cependant, la moitié des juridictions n'ont pas introduit cette réforme. Notre étude révèle que parmi les facteurs d'échec on peut compter une conceptualisation généralisée de la victime comme prétendue victime, et l'attribution de la tâche d'information aux instances judiciaires plutôt qu'à la police. Dans les juridictions où la responsabilités d'informer existe en tant que fonction formelle, la possibilité d'échec est surtout liée au fait que la police ne s'acquitte de cette tâche que de façon symbolique. Parmi les facteurs favorisant l'application de ces nouvelles dispositions, il y a la mise en place d'incitatifs au plan organisationnel, l'élaboration de systèmes de contrôle, et la référence systématique des victimes à des services sociaux, d'appui, de conseil et d'assistance juridique. Pour améliorer la transmission des informations, on devrait prévoir des fonds pour financer ce type d'activités, qu'elles soient menées par la police ou par d'autres instances.

En ce qui concerne le dédommagement, la recherche démontre que l'ordonnance de dédommagement, surtout le modèle anglais, est plus efficace que le modèle partie civile ou la mesure de dédommagement hollandaise. Le principal facteur de réussite de l'ordonnance de dédommagement est qu'elle est une mesure pénale imposée par l'État. Cela veut dire que la responsabilité civile n'est pas un prérequis et que la Cour peut ordonner le dédommagement qu'elle considère approprié en tenant compte du statut financier de l'inculpé. De plus, la Cour est obligée de considérer la possibilité d'émettre l'ordonnance de dédommagement, et d'expliquer pourquoi elle n'est pas imposée. Un facteur d'échec dans le cas du modèle partie civile c'est qu'il comporte une « clause d'évasion » : les réclamations peuvent être référées à la Cour civile. Un facteur d'échec de la mesure de dédommagement, c'est qu'elle est une sanction pénale régie par la loi civile. En pratique, elle ressemble au modèle partie civile : les deux se confondent.

La manière dont les instances judiciaires traitent les victimes peut être améliorée en leur fournissant une formation visant à les conscientiser aux besoins des victimes. Donner cette formation aux nouvelles recrues seulement serait un facteur d'échec, car elle ne peut être efficace que si elle est offerte à l'ensemble du personnel. Offrir des cours de recyclage et en mesurer les effets sur la performance sont des facteurs de réussite. Un facteur d'échec est lié au fait que ce type de formation est perçu par les instances judiciaires comme une menace à leur indépendance professionnelle.

Les facteurs de réussite en ce qui concerne l'interrogatoire des victimes reposent sur une formation spécifique et la mise en place d'installations spéciales : par exemple, salles d'entrevue pour les enfants, salles d'attente pour les victimes de crimes sexuels, enregistrement audiovisuel avant le procès, et interrogatoires à distance par moyens vidéo. De telles mesures améliorent la qualité du système pénal dans son ensemble.

Un moyen fréquent de protéger les victimes est de mener le procès, ou du moins une partie du procès, à huis clos. Le fait que les instances judiciaires s'opposent (fortement) à cette façon de faire représente un facteur d'échec. Créer une obligation formelle pour 
la Cour de mener tous les procès impliquant des crimes de nature sexuelle à huis clos serait un facteur de réussite.

Nous concluons que le succès des réformes axées sur les victimes dépend, inter alia, de la clarté et de la précision de telles réformes, de l'absence de " clauses d'évasion », de l'attitude des décideurs du système pénal, et de la possibilité que ces réformes puissent être bénéfiques au contrevenant et (ou) au système pénal dans son ensemble.

ABSTRACt - The 1985 UN Declaration of Basic Principles of Justice for Victims of Crime and Abuse of Power, and the Council of Europe's Recommendation (85) 11 on the Position of the Victim in the Framework of Criminal Law and Procedure are important documents that reflect an international consensus on legal rights for victims.

In many European jurisdictions, such victims' rights have been introduced or improved upon. However, they are often not used as intended or remain virtually dormant. The UN has therefore adopted a Resolution and drafted a manual on ways to facilitate effective implementation. In addition, certain jurisdictions have proved sensitive to implementation problems. The Netherlands, for example, put the new Victim Act into effect on an experimental basis in two legal districts to carefully evaluate the effects of new provisions, and to apply the resulting knowledge when expanding its territorial scope.

However, more sophisticated instruments are needed to set implementation parameters at a supra-national level. To this effect, we conducted a comparative study of both a legal and empirical nature in 22 member states of the Council of Europe. The study revealed, inter alia, critical factors of failure or success. The workings of these critical factors in the implementation of Recommendation (85) 11 are demonstrated by drawing upon illustrations taken from the reality of certain jurisdictions. The examples are subdivided into four major themes: information, compensation, treatment and protection.

As the second guideline of Recommendation (85) 11 expresses, the creation of a formal duty for the police to provide victims with information about the possibilities of obtaining assistance, legal aid and compensation is vital. However, in half of the jurisdictions, no such reform has been implemented. Our study reveals that critical factors of failure are, among other things, a widespread conceptualization of the victim as an alleged victim and the creation of an information duty for the judicial authorities instead of for the police. In jurisdictions where an information duty has been created, failure depends, first of all, on whether the police are content with a symbolic fulfillment of this task. Critical factors needed to improve successful implementation are the creation of organizational incentives, monitoring systems, and systematic referral to victim support, legal aid and social or counseling services. A final step to improve implementation of information duties would be financial compensation earned for victim-related activities carried out by the police and other authorities.

Concerning compensation, research reveals that the compensation order, particularly the English one, is more successful than the partie civile model or the Dutch compensation measure. The most important critical factor of success of the compensation order is that it is a penal sanction, enforcable by the state. This means that civil liability is not a prerequisite and that the court can order an amount of compensation it considers appropriate while taking the financial capacity of the offender into account. 
Furthermore, the court is obliged to consider making a compensation order and to explain why it was not imposed. A critical factor of failure of the partie civile model is that it includes an easy escape clause: claims can be referred to civil court. A critical factor of failure of the compensation measure is that it is a penal sanction governed by civil law. In practice, it resembles the traditional partie civile model: the two are blended into one.

The way victims are treated by criminal justice authorities can be improved by providing victim-awareness training. A critical factor of failure is to only train recruits. Training is only effective if it is extended to incumbent personnel. Giving refresher courses and measuring the effects of training in performance assessments are factors contributing to success. A critical factor of failure in such training for judicial authorities is the argument that it would compromise their independence.

Critical factors to improve the questioning of victims are the provision of specific training courses and the creation of special facilities, e.g. interviewing studios for children, suites for victims of sexual offences, audio-video recording of pre-trial examinations and video-linked questioning. Such reform measures benefit the quality of the criminal justice process as a whole and therefore prove to be successful.

A common manner of protecting victims is to allow that a trial, or a part thereof, be conducted in camera. A critical factor of failure is the (very) reluctant attitude of the judiciary toward holding a trial behind closed doors. A critical factor of success is the creation of a formal duty for the court to hold all cases involving sexual offences in camera.

We can conclude that successful implementation of victim-oriented reforms depends on, inter alia, the clarity and conciseness of reform measures, the absence of easy escape clauses, the attitude of criminal justice authorities, and whether the reforms also benefit the offender and/or the criminal justice system as a whole.

Resumen - Tanto la Declaración de las Naciones Unidas sobre los Principios Básicos de Justicia para las Víctimas del Delito y del Abuso de Poder (UN Declaration of Basic Principles of Justice for Victims of Crime and Abuse of Power, 1985), como las Recomendaciones del Consejo de Europa (85) 11 sobre la Situación de la Víctima en el Marco de la Ley Penal y Procedimental (Council of Europe's Recommendations $(85,11$ ) on the Position of the Victim in the Framework of Criminal Law and Procedure), constituyen documentos importantes que demuestran el consenso internacional en cuanto a los derechos vigentes que protegen legalmente a las víctimas.

En un gran número de naciones europeas, estos derechos de la víctima han sido hasta ahora incorporados a sus legislaciones, o perfeccionados. No obstante, ocurre que estos derechos no suelen ser ejercidos en la forma en que fueron concebidos, o permanecen inactivos. Como consecuencia de ello, la Organización de Naciones Unidas ha adoptado una resolución y elaborado un manual sobre formas y medios que facilitan la implementación de estos derechos. Aparte de ello, algunos países se han ido sensibilizando frente a los problemas relacionados con esta implementación. En este sentido, en los Países Bajos se puso en vigencia experimental una Ley sobre las Víctimas dentro de dos distritos jurídicos, con la finalidad de evaluar cuidadosamente las nuevas pre- 
visiones y de esta manera aplicar los conocimientos adquiridos, una vez que se extendiera su alcance territorial.

Sin embargo, se necesitan actualmente instrumentos refinados que permitan examinar a fondo los parámetros de implementación en el nivel supra-nacional. Hasta el momento, hemos llevado a cabo un análisis comparativo de los aspectos legales y empíricos en 22 Estados miembros del Consejo de Europa.. El trabajo revela, entre otras cosas, la presencia de factores críticos en lo que respecta a los éxitos y fracasos. La influencia de estos factores al momento de ser implementadas las Recomendaciones del Consejo (85) 11, se pone de manifiesto al seleccionarse los ejemplos tomados de la realidad en algunas jurisdicciones. En tal sentido, subdividimos los ejemplos en cuatro temas centrales: información, compensación, tratamiento y protección.

Tal como lo indica la segunda pauta de las Recomendaciones (85) 11, la adopción de una obligación formal por parte de los cuerpos policiales, en cuanto a suministrar información a las víctimas sobre las posibilidades de asistencia, asesoría legal y compensaciones, es, en todo caso, fundamental. Sin embargo, en la mitad de las jurisdicciones dicha reforma no ha sido implementada hasta este momento. Nuestro estudio pone de manifiesto que entre los factores criticos vinculados al fracaso se encuentran, entre otros, la conceptualización ampliamente difundida de la víctima como simple supuesta víctima, así como el establecimiento de la obligación legal en cuanto a las autoridades judiciales en lugar de vincularse a los cuerpos de policía. En aquellas jurisdicciones en las cuales quedó establecida la obligación de suministrar esta información, el fracaso depende, en gran medida, de si la policía se considera satisfecha o no con el cumplimiento simbólico de esta tarea. Los factores críticos que ayudan a mejorar la implementación exitosa están representados en la creación de incentivos organizacionales, de sistemas de comprobación y la referencia sistemática a la asistencia a la víctima, así como a la asistencia legal y a la presencia efectiva de los servicios sociales o de orientación. Un elemento final que puede contribuir a la implementación de este deber estatal de suministrar información, vendría a ser la asignación de fondos destinados a las actividades de la víctima en todo lo que respecta a sus relaciones con la policía y otras autoridades.

Por lo que se refiere a la compensación, la investigación revela que la sentencia que la ordena, especialmente la de origen inglesa, tiene más éxito que la decisión de acerdo al modelo de la partie civile, o que la llamada compensación holandesa. El factor crítico de mayor importancia para el éxito en la sentencia de compensación radica en que la misma constituye una sanción penal, aplicada por el Estado. Ello significa que la responsabilidad civil no constituye un pre-requisito de la misma y que la corte puede fijar el monto por compensación que considere ajustado, tomando en consideración la capacidad económica del transgresor. Aún más, la corte está obligada a considerar la imposición de una orden de compensación y a explicar por qué razón la misma no fue ejecutada. Un factor crítico ligado al fracaso del modelo partie civile que este suele incluir una cláusula de fácil evasión : las reclamaciones pueden ser referibles a una corte en lo civil. Asimismo, un factor crítico ligado al fracaso de la medida de compensación es que la misma representa una sanción penal regulada por la ley civil. En la práctica, esta modalidad se asemeja bastante al modelo tradicional de la partie civil, y al final, ambas suelen terminar confundidas.

La forma en que la víctima es tratada por las autoridades del sistema penal puede mejorarse a través de un entrenamiento dirigido a despertar la toma de consciencia 
de la víctima misma. Igualmente, un factor crítico ligado al fracaso consiste en entrenar sólo a voluntarios. El entrenamiento sólo resulta provechoso si se hace extensivo al personal que corresponde. Suministrar cursos de actualización y medir los efectos del aprendizaje en las evaluaciones de resultado son factores favorables al éxito. Un factor importante vinculado al fracaso, por lo que respecta a este entrenamiento en el caso de las autoridades judiciales, suele ser el argumento de que el mismo puede poner en peligro su independencia.

Por otra parte, algunos factores importantes que contribuyen a mejorar el interrogatorio de las víctimas consiste en proveer cursos específicos de entrenamiento, así como crear instalaciones especialmente dotadas para ciertas actividades, como por ejemplo, locales para realizar entrevistas infantiles, o habitaciones acondicionadas para el caso de víctimas de delitos sexuales, la filmación en audio-video de interrogatorios previos al proceso, al igual que los interrogatorios simultáneos o múltiples mediante los sistemas de video. El conjunto de estas medidas resulta provechoso con respecto a la calidad del proceso penal visto como un todo, y en consecuencia, suele demostrar su utilidad.

Una manera usual de proteger a las víctimas consiste en permitir que el proceso, 0 al menos una parte de él, se desarrolle en privado (in camera). Un factor importante de fracaso se suele hallar en la actitud (generalmente) reacia del poder judicial, frente a la necesidad de llevar a cabo algunos procesos a puertas cerradas. Un factor crítico de éxito, en cambio, radica en establecer la obligación legal a las cortes a fin de que los procesos penales que se relacionen con infracciones de naturaleza sexual sean llevados regularmente a cabo in camera.

Podemos concluir señalando que una implementación exitosa de las reformas orientadas hacia la protección de la víctima depende, entre otras cosas, de la claridad y concisión de las medidas establecidas en la reforma, de la ausencia de cláusulas y condiciones de fácil evasión, así como de las actitudes por parte de las autoridades de orden penal, y de si, de un modo u otro, las reformas benefician igualmente al transgresor y/o al sistema de justicia penal vistos como un todo.

\section{Introduction}

Since the early seventies, European researchers have conducted an ever increasing number of empirical studies in order to better understand the incidence and actual meaning of criminal victimization (Joutsen, 1997). One has to know the extent of a problem before dealing with it. Hence the development of victim surveys. The surveys demonstrated that in Europe, roughly speaking, about one out of four citizens is victimized each year. And it was shown that the impact of crime is usually much more severe than victims anticipate. This applies not only to the most serious instances of crime (capital cases, violence and sexual crime), but also to the more frequently occurring types of property crime. Many victims subsequently suffer from shattered confidence in society: they 
lose trust in other human beings and they lose faith in an ordered world (Van Dijk, 1996: 121-132). ${ }^{1}$ Moreover, it became evident that there is a major risk of secondary victimization by the agencies operating the criminal justice system. The only way to avoid this is to pay attention to the real needs of victims. Again, research indicated which needs and interests should be considered (Vilmow, 1985: 105-142; Joutsen, 1989: 50-83; Walklate, 1989). It turned out that being treated with respect and recognition is crucial; information is essential in order to avoid alienation. Restitution paid by the offender facilitates the coping process. And finally, two overall considerations became apparent. The first involves the concept of procedural justice: for most victims, the process counts more than the outcome (Wemmers, 1996). The second is the axiom that in dealing with criminal victimization one should never raise expectations which cannot be fulfilled.

During the past decade and a half, these research findings have gradually been integrated into various European jurisdictions in a twofold manner. On the one hand, there have been widespread efforts to reform the criminal justice systems for the benefit of victims. And on the other hand, in many countries large victim support organizations were established to provide services and assistance (Groenhuijsen, 1998: 15-24). It is worth noting that these developments are closely connected. They represent strategies which mutually reinforce one another and which share the same overall objectives:

- to limit the adverse consequences of victimization, i.e. damage control and facilitation of the coping process;

- to avoid inflicting additional harm;

- to promote restitution and compensation;

- and to prevent repeat victimization.

Against this background, the still frequently uttered claim that the victim is "the forgotten party" in the criminal justice system no longer applies. The victim was rediscovered quite some time ago and many European jurisdictions have acted accordingly. In this context, we will first point out the resulting "state of the art" in terms of victims' rights and services. Next, we will argue that attention has since shifted to implementation issues. In the subsequent sections we will report some major findings of an extensive research project carried

1. The surveys also refuted the notion of crime victims as over-emotional and vengeful persons with a lust for harsh punishment. 
out in 22 member states of the Council of Europe. The paper will close with some final observations.

\section{"State of the art" Victims" Rights and Services}

In 1985, the General Assembly of the United Nations adopted the Declaration of Basic Principles of Justice for Victims of Crime and Abuse of Power. In the same year, the Council of Europe issued its Recommendation on the Position of the Victim in the Framework of Criminal Law and Procedure. And finally, in 1996, the European Forum for Victim Services published a Statement of Victims' Rights in the Process of Criminal Justice. In our opinion, these documents reflect an international consensus on the type of legal rights victims must be accorded within the framework of criminal justice systems: basic minimum rights to be observed in every case of criminal victimization. ${ }^{2}$ The list comprises the right to:

- respect and recognition;

- receive information and explanation about the progress of the case;

- provide information;

- legal advice and representation, regardless of means;

- protection of privacy and physical safety;

- restitution and compensation. ${ }^{3}$

Likewise, in Europe there is widespread agreement on the guiding principle that victims should have the basic right to a system of free Victim Support services, staffed by trained volunteers or professionals. This should include the right to:

2. It has to be noted, though, that the international documents cited have varying legal status. For instance, these instruments differ in the extent to which national governments have to sign up to them and what action they need to take consequently. Both the UN Declaration and the Council of Europe Recommendation create the presumption that national governments will start to modify their criminal justice systems in this respect, but no time limit is specified. The European Forum Statement does not have any legal status at all.

3. These rights are quoted from the European Forum Statement of Victims' Rights in the Process of Criminal Justice. This document contains the most elaborate explanation of the rationale and the implications of the legal requirements. As far as substance is concerned, the differences from the UN Declaration and the Council of Europe Recommendation are only marginal. 
- equal access to Victim Support services;

- support by selected and trained personnel;

- services which are confidential;

- personal autonomy over decisions taken;

- services which are independent. ${ }^{45}$

In many European jurisdictions these types of rights have been introduced or improved upon during the past decade and a half. ${ }^{6}$ The legal provisions which were added differ in detail and specifics, but they all conform to the same pattern. It has to be acknowledged, though, that quite a few elements of these reformist measures had been part of the legal systems for a long time. For instance, provisions on restitution have been in place from time immemorial. The problem is that traditionally they have not been used as intended; some of them have even remained virtually dormant. Newly introduced victims' rights are threatened with the same fate. So the really interesting challenge today is to find out how effective implementation of these legal provisions can be achieved (Groenhuijsen, 1999: 85-144).

\section{Implementation: the First Stage}

Awareness of the primacy of implementation issues was first raised on the international level by the United Nations. As early as 1986 the Economic and Social Council adopted Resolution 1986/10 on ways and means to facilitate effective implementation of UN Resolutions. Subsequently, a long list of specific proposals was developed in order to give effect to the various ingredients of UN Declaration 40/34 (Cherif Bassiouni, 1988). The next step was to conduct a survey in the member states to monitor progress (1995). It turned out that the Declaration generally appears to enjoy respect in most states, but that additional action is still required: continuing to promote research, technical assistance, exchange of experience and model examples of legislation. This

4. Quoted from the Statement of Victims' Rights to Standards of Service, published by the European Forum for Victim Services in 1999.

5. The European Forum also adopted a more ambitious document in 1998, outlining the social rights of victims of crime. These rights include, inter alia, the right to have access to health care services, to have access to appropriate home security measures, and the right to receive support and protection in the workplace as well as in educational establishments.

6. For instance, Belgium: the Franchimont Act (1998), the Netherlands: the Terwee Act (1995), England and Wales: Victims' Charter (1996), Germany: Opferentschädigungsgesetz (1976) and the Zeugenschutzgesetz (1998), Switzerland: Opferhilfegesetz (1991). 
led to the drafting of a so-called "Manual on the Use and Application of the Declaration of Basic Principles of Justice for Victims of Crime and Abuse of Power", which was finalized in 1998.

On a national level, quite a few countries have proved their sensitivity to problems of implementation. One interesting example is the way new victim-oriented legislation was introduced in the Netherlands. ${ }^{7}$ In an effort to avoid raising unfulfillable expectations, the legislative decided to put the new Terwee Act into effect on an experimental basis in only two of the nation's 19 judicial districts. ${ }^{8}$ The rationale behind this approach was to carefully evaluate the effects of the new provisions, and then apply the resulting knowledge when expanding the territorial scope of the Act. It turned out that it is relatively easier to make progress in providing victims with the information they are entitled to, than in promoting restitution by offenders to victims (Slotboom and Wemmers, 1994). Secondly, it became evident that reforms of this kind can only be effected by creating a network of all the major actors involved in operating the criminal justice system. Thirdly, it was established that money does not always determine the outcome of a project. On the other hand, change cannot be effected without supplying adequate resources to the agencies who have to assume additional burdens. And, as we already knew from previous experience, implementation requires a supportive attitude on the part of all officials involved in applying reform, an attitude which needs to be backed up by knowledge of victims' issues.

In a nutshell, this is how the Dutch tried to make the new policies work well in practice. On the one hand, the method used is daring yet epistemologically sound. We know of no other case where an experiment has been conducted on such a large scale, differentiating the legal status of victims according to the district where they reside. But on the other hand, it cannot be denied that the experiment failed in large measure: the introduction of the Act in the remaining 17 legal districts was in actual practice hardly affected by the experience gained in the pilot districts.

The conclusion to be inferred from these - and other - episodes is that we need still more sophisticated instruments to establish implemen-

7. The example concerns the so-called Terwee Act. The Act provides for more informational rights, better opportunities to claim restitution in criminal court, and reparation as a penal sanction in its own right.

8. The Act acquired force of law on April 1st 1993 in the pilot districts, and two years later in the remaining parts of the country. 
tation parameters. In the following sections, we shall present some of the latest research findings allowing us to better understand why certain reform measures fail while others succeed.

\section{Implementation: Toward a More Sophisticated Approach}

In the past four years, two researchers from Tilburg University (Marion Brienen and Ernestine Hoegen) have carried out a comparative study of both a judicial and empirical nature in 22 member states of the Council of Europe. ${ }^{9}$ The object of their research was to study the implementation of Recommendation (85) 11 in the states that were members in 1985, taking into account previously conducted studies, which were subjected to a process of meta-evaluation. The first purpose of the research was to gain knowledge about the formal and actual implementation of Recommendation (85) 11. Secondly, was a desire to understand, on the one hand, why jurisdictions do not attain the formal requirements set out in Recommendation (85) 11, and on the other hand, why certain reform measures succeed where others fail.

One interesting outcome of the research is the concept of developmental scales regarding the creation of victim-oriented reform measures, as well as their factual implementation. The developmental scales give an overview of developments in Europe. At the same time, the consecutive stages in formal and actual development represent successive steps towards a genuine improvement of the position of victims within the criminal justice system (see developmental scale, next section). In this respect, the developmental scales provide a clear insight into the current state of affairs in formal and actual implementation. Furthermore, critical factors of failure or success are revealed. These critical factors are often closely connected with the local realities of a particular jurisdiction (Brienen and Hoegen, 1999).

To demonstrate the workings of these factors which determine success or failure of reform measures, we have drawn upon illustrations taken from the reality of certain jurisdictions. The examples are subdivided into four major themes: information, compensation, treatment and protection. ${ }^{10}$

9. The project was conceived and supervised by Marc Groenhuijsen; it was co-funded by the Dutch Ministry of Justice.

10. All the basic rights contained in the UN Declaration and the Council of Europe Recommendation fall into one of these four general themes. 


\section{Information}

Recommendation (85) 11 begins with a guideline that establishes a duty ${ }^{11}$ for the police to provide information to victims about their legal rights and opportunities. Currently, no such duty is established in the members states which find themselves at stage 0 . Reform measures have led to a partial obligation for the police to inform the victim in countries adhering to stage 1 . A full formal obligation for the police has been set up in the seven jurisdictions of stage 2 . The latter jurisdictions have therefore attained the highest level of formal sophistication.

Devlopmental scale formal implementation guideline A2

stage 0 - No implementation: Cyprus, France, Germany, Greece, Italy, Liechtenstein, Luxembourg, Malta, Portugal, Scotland, Sweden and Turkeystage 1 - Partial implementation: Austria, Iceland and Switzerland

stage 2 - Full implementation: Belgium, Denmark, England and Wales, Ireland, the Netherlands, Norway and Spain

Developmental scale actual implementation guideline $A .2^{12}$

stage 1 - Information is seldom provided: Cyprus, France, Germany, Greece, Italy, Liechtenstein, Luxembourg, Malta, Portugal, Scotland and Turkey

stage 2 - Limited information is provided: Austria, Iceland, Spain and Switzerland

In jurisdictions where no reforms were introduced to create a formal obligation, local realities may offer an explanation for this failure. In Greece, for instance, the victim is generally perceived as an "alleged" victim until the court has proven this to be otherwise. ${ }^{13}$ Consequently, little incentive exists to improve the victim's position in the (pre-)trial stage. Alternatively, local realities may cause the introduction of inappropriate reform measures. In France and Portugal, certain informatory obligations for the prosecution service were created concerning specific procedural moments. The French and Portuguese legislatures failed,

11. In footnote 2 above, the legal status of the concept of "duty" has been clarified in this framework.

12. In the model on actual development, we have not included a stage 0 because in all jurisdictions some sort of information is provided to victims. No criminal justice system systematically withholds all information from victims.

13. Personal communication with numerous Greek legal practitioners, e.g. police officers, prosecutors, judges and lawyers. 
however, to establish a general basic duty for the police to inform victims. In Germany and Sweden, on the other hand, a formal obligation was created but the legislature failed to designate the responsible agent. ${ }^{14}$ In German legal practice the prosecution service informally assumed the responsibility for informing victims. ${ }^{15}$ This represents a critical factor of failure. Not only because numerous victims are not reached by the prosecution service, but also because public prosecutors are less easily persuaded to carry out this duty. German research (Kaiser, 1992; Kury et al., 1994: 72-76) clearly demonstrates this often unwilling attitude of public prosecutors provide information. According to these studies, $32 \%$ of public prosecutors feel this informatory duty to be unessential. Moreover, $60 \%$ of public prosecutors stated that there is no suitable opportunity to give information. When asked about the actual provision of information, $26.3 \%$ of public prosecutors admitted to never informing the victim, and $44 \%$ only gave information after a specific request from the victim. As a result, only $25.7 \%$ of victims said they were sufficiently informed about their rights.

Local realities, however, may also lead to factual success in spite of a failure of the legislature to introduce adequate reforms. In Sweden, the police spontaneously assumed the task of informing victims. ${ }^{16}$ Their level of awareness of victims' needs is a critical factor of success which remedies the official policy concerning victims. Inversely, local realities may cause the failure of reform measures. In Portugal, where the prosecution service has delegated its responsibility to the police, not much actual success is attained. The content of the information letter the police should hand out is far too complicated to be understood by the average victim, and no oral explanation is offered by the police. The fact that $10 \%$ of men and $17 \%$ of women are illiterate, and that only $65 \%$ and $59 \%$ respectively attended primary school is not duly taken into consideration by the authorities (Inquérito de Victimação, 1994; Brienen and Hoegen, 1998).

In jurisdictions which have reached the highest level of formal development (stage 2), actual failure or success seems to depend on other

14. Germany: ss. $403-2$ and $406 \mathrm{~h}$ Code of Criminal Procedure; Sweden: s. 13a Ordinance on Preliminary Investigations.

15. In Sweden, the police has assumed responsibility; see Swedish National Police Board, letter of June 21, 1994, to all local police authorities.

16. Letter and guidelines of June 21, 1994, of the National Police Board to all local police authorities, POB-480_5651/93. 
factors. In Spain, failure is mainly caused by the attitude of the authorities toward reform measures (González Gil et al, 1997: 104). The police are content with the symbolic fulfillment of their duties: obtaining the victim's signature on a form as proof of the fact that an information letter has been handed over. On the other hand, a crucial factor for the successful introduction of a formal victim-oriented duty is its official embedding in the police job description. The police force must recognize the new duty to provide victims with information as a basic police task. This is achieved in Belgium and the Netherlands. ${ }^{17}$ The creation of organizational incentives is equally crucial. Public prosecutors and chiefs of police should supervise the actual implementation of duties, establish target figures regarding information, and monitor achievements. Data thus obtained can be used by the police to make an objective calculation of finances needed to fulfill their duties toward victims in a proper manner. In the Netherlands, organizational structures and monitoring systems have been set up. However, the monitoring systems have a long way to go. In addition, the development of strategies to enhance the quality of information is critical to actual success. One such strategy is that the police provide general and basic information, and then systematically refer victims who need more detailed information or practical or legal assistance to victim support, legal aid, social or counselling services (Belgium, England and Wales, Ireland, the Netherlands and Sweden). ${ }^{18}$

Finally, the Ministries of Justice and the Interior should earmark funds as exclusively destined to pay for victim-related activities, because the allocation of financial means should not be related exclusively to crime fighting. Unfortunately, this measure has not been implemented in any of the 22 jurisdictions. It is not even under consideration except in the Netherlands.

17. Belgian Guideline OOP 15 bis, 1994; Dutch Terwee Guideline, 1995. In both these jurisdictions, the content of the guidelines was incorpored into police training programs for recruits and incumbent personnel.

18. Belgium: Belgian Victim Support, Statistics 1994-1996, Berchem, (43.9\% of the clients were referred by the police); England and Wales: Victim's Charter 1996; Ireland: Gardaí Head Quarters circular 21/98 Victim Support and Charter for Victims of Crime, 3 February 1998; The Netherlands: Victim Support the Netherlands, Victim Support in the Netherlands, July 1997, p. 4 (75\% of the clients were referred by the police); Sweden: Lindgren, M., Christianson, S.A., Relationen Mellan Polis och Brottsoffer i Stockholms Polismyndighet, PHS Rapport 1994: 2, Polishögskolan Forskningsheten December 1994, and personal communications with Victim Support Sweden. 
In conclusion, we see that of the seven jurisdictions which have reached the highest level of formal success, only four have achieved genuine actual success. Only one country, Sweden, has achieved actual success without the existence of proper victim-oriented reform. This demonstrates the relevance of victim awareness among judicial authorities.

\section{Compensation}

Concerning compensation, we will show one example of legal reform that has proven to be successful, i.e., the English compensation order, and two examples of reforms that have largely failed, i.e., the introduction of the Dutch version of the compensation order and the measures to revise the adhesion model or partie civile model.

The compensation order exists in Cyprus, England and Wales, Ireland, Malta and Scotland. The main advantage of the compensation order over the adhesion model is its enforcement by the state in the same manner as fines. Among these five states, the compensation order is the most successful in England. ${ }^{19}$ Several factors have contributed to its success in that country. A most crucial factor of success has been the introduction of the 1988 legal reform measure which obliges the criminal courts to always consider making a compensation order of their own accord (Criminal Justice Act). What is more, the courts are obliged to explain if, and why, they have not imposed a compensation order in a suitable case. Other measures that were taken in 1988 were, firstly, to draw up sentencing guidelines in relation to personal injury, ${ }^{20}$ which greatly facilitated imposing compensation orders for injuries of the victim, and secondly, to give the police the duty of ensuring that all relevant information about the injuries and losses suffered by the victim is included in the file forwarded to the prosecution service and eventually to the court. ${ }^{21}$ Another critical factor which reinforces the ability of the criminal court to order the payment of compensation to the victim is that civil liability is not a prerequisite (Chappell (1984) $80 \mathrm{Cr}$ App R 31). As a result, the court orders the amount of compensation that it considers

19. In 1994, the magistrates' courts made compensation orders in $22 \%$ of the convictions for indictable offences, and the Crown Courts in $9 \%$. See Home Office Criminal Statistics 1994, Digest 3, 1995. For a European comparison, see Brienen and Hoegen (2000a), chapter 26.

20. Home Office, Guidelines on Compensation, 1988.

21. Home Office Circular 201988. 
"appropriate", having also taken the offender's financial status into account (Powers of Criminal Courts Act 1973, s. 35-1a and -4).

Contrary to the compensation order, the Dutch model failed to produce success. The Dutch legislature was greatly inspired by the relative success of the English compensation order compared to the adhesion model (Junger and Van Hecke, 1988), ${ }^{22}$ and wanted to emulate this reform measure, particularly because it would give the victim a less complicated method of obtaining compensation compared to the traditional adhesion procedure. Besides, an important advantage of the compensation order is its enforcement by the state. In practice however, the Dutch version of the compensation order has not lived up to expectations. In hindsight, we can say that the Dutch legislature made a fatal error in construction (Brienen and Hoegen, 2000b). Instead of adopting a full-fledged compensation order which is a full penal sanction, it opted to tone it down to a compensation measure. In the Dutch sanctioning system, this is not a pure penal sanction because it is governed by civil law. The legislature argued that compensation is by nature a matter of civil law and cannot be a true to type penal sanction. The measure does not intend to inflict harm on the offender in retribution for the crime committed. It primarily seeks a restoration of the situation that existed prior to the crime. As a result, the compensation measure requires as a condition for its imposition that the offender's liability under civil law be established. With this requirement, the flexibility of the compensation order is lost. What is more, the compensation measure becomes little more than a veiled version of the traditional civil claim for compensation under the adhesion procedure. The only real difference is enforcement by the state. Not surprisingly, legal practitioners, including the judiciary, became seriously confused. Courts have started to blend the compensation measure and the adhesion procedure into one new, hybrid compensation model. The courts award compensation to the victim as a civil claimant and at the same time order the offender to pay the compensation measure for the same amount. In the verdict, they enter a clause stating that payment of the civil claim relieves the offender from payment of the compensation measure, and vice versa (Claassens and Stoker-Klein, 1995: 167-175). Judges do this with the best intentions, feeling they give the victim the best of both worlds. What

22. This 1988 study shows (p. 77-78) that only $4.2 \%$ of victims assumed the role of civil claimant and initiated criminal proceedings to claim compensation, and even fewer victims (3.3\%) were granted compensation. This despite the fact that in $82 \%$ of the cases victims suffered losses and injuries caused by a punishable act. 
they fail to see is that they effectively kill the purpose of the legal reform, which is to improve the victim's chances of receiving compensation, by adding an attractive, easy-to-operate alternative to the low success-rate adhesion procedure. Due to the error in the construction of the legislature and the factual implementation of the reform, the compensation measure is in fact again burdened with all the shortcomings of the adhesion procedure that it was supposed to have done away with (Brienen and Koopmans, 1998).

Besides this fundamental problem of the compensation measure, the introduction of enforcement by the state was not very successful either. Initially, the prosecution service was responsible for the collection of the compensation measure, which turned out to be another miscalculation. The prosecution service was very ineffective in enforcing the measure. It lacked experience in collecting money because financial penalties are collected by the debt collection agency. Moreover, it did not have the manpower to pursue unwilling offenders and force them to pay. After one and a half years, the legislature recognized its error and allowed the national debt collection agency to enforce the compensation measure. Unfortunately, the stigma of inefficiency and bad performance remained, even though the debt collection agency is an experienced and successful collector of money on behalf of the state or the victim. ${ }^{23}$

Ironically, only the Dutch legal reform measure achieved effective enforcement by the state. This, however, can be done by more simple means, as in shown by Swedish practice. The Swedish legislature achieved the same results by simply allowing the debt collection agency to collect compensation on behalf of the victim after explicit consent by the victim (SOU, 1998: 40. See Justice departement, 1998). Here too, however, mistakes were made in the initial phase. The letter sent to the victim to obtain written consent was written in legal jargon and did not mention that the service is free of charge. This error has now been remedied. The redesigned letter will definitely be more successful. Contrary to the Dutch situation, the risk of long-term stigmatization is much smaller here because the letter is addressed to individual victims who, for the most part, have not received such a letter before, and know from their own experience with paying fines that the agency is quite effective in collecting money.

23. B \& A Groep, 1998: 81-83. See also Brienen and Hoegen, 2000a: chapter 17; Brienen and Hoegen, 2000b. 
Finally, legal reform measures regarding compensation often aim at improving the performance of the adhesion procedure or partie civile model, which is found in the Germanic, Romanistic and Nordic jurisdictions. Ordinarily, legislatures allow the criminal courts to refer for compensation in civil court civil claims that are "too complicated" (Brienen and Hoegen, 2000b). The reasoning behind this stipulation is that the question of compensation should not undermine the criminal court's focus on the criminal case at hand. In practice, however, this provision offers a very easy escape route for judges who are unwilling to deal with the victim's claim for compensation during criminal trial proceedings. At the same time, these judges do not feel they deprive the victim of a chance to obtain compensation because civil proceedings remain still open. This is a common but false presumption, because in an average case of claim for compensation, litigation costs greatly exceed possible benefits. Therefore, this escape route causes many of the legal reforms related to the adhesion procedure to fail in practice.

\section{Treatment}

Training

It is widely accepted that those dealing with victims of crime should be trained to improve the treatment of victims. They should learn to understand the needs of victims, and how best to approach them. This applies both to victim support workers and the judicial authorities. The victim support services associated with the European Forum for Victim Services all have well-developed programs for training their own volunteers and professional staff. Volunteers are instructed on such diverse subjects as listening and communication skills, emotional needs of victims, victims' legal rights, referral to other agencies, media skills and needs of special victim groups. ${ }^{24}$

Likewise, according to international standards explicitly embodied in the United Nations Declaration and Recommendation (85) 11 of the Council of Europe, ${ }^{25}$ the police should receive appropriate training in dealing with victims of crime, if only because the police are usually the first authority that the victim comes into contact with. National standards of victim-oriented training of police officers, however, vary

24. See European Forum for Victim Services, Training Survey 1999, First Results.

25. Guideline A.1 of R (85) 11 of the Council of Europe provides that the police should be trained to deal with victims in a sympathetic, constructive and reassuring manner. 
considerably between different jurisdictions. In some, the police receive no such training at all (France, Greece, Italy, Liechtenstein, Malta, Portugal, Spain and Turkey) (Brienen and Hoegen, 2000a: chapter 27' 2). In others, a module on victims is included in the basic training of new recruits, although more often than not, it is limited to an hour or two on a Friday afternoon, which is not the best time for an attentive audience. Or, it is limited to one particular group of victims. In Cyprus, police recruits are trained regarding victims of domestic violence exclusively. Only eight out of 22 jurisdictions provide training to incumbent personnel as well as to recruits (Belgium, Denmark, Iceland, Ireland, Luxembourg, the Netherlands, Norway and Scotland) (Brienen and Hoegen, 2000a: chapter $27^{\prime}$ 2). Ideally, refresher courses should be given and the effects of training should be measured in performance assessments. This is a reform measure that is not yet implemented, but is highly recommended in order to achieve the highest possible stage of factual success.

Concerning the other criminal justice authorities, however, a surprising degree of resistance exists. The prosecution service and the judiciary generally oppose the proposition that they, too, should receive appropriate training on how to deal with victims of crime. The judiciary, in particular, argue that such training would compromise their independence. Victim-oriented training for prosecutors and judges is a level of sophistication that most jurisdictions have not yet managed to attain. The only exceptions here are England and Wales, and the Netherlands. In the Netherlands, all public prosecutors and trainee judges, including incumbent members of the prosecution service, are obliged to follow a victim-oriented course. ${ }^{26}$ Incumbent members of the judiciary, however, are not trained because they claim this would compromise their independence. In England and Wales, both public prosecutors and magistrates receive training on how to deal with victims of crime. ${ }^{27}$

\section{Questioning}

With regard to the examination of victim-witnesses, the highest level of formal and actual success is attained by jurisdictions which have created special questioning facilities for the most vulnerable victim-witnesses. The establishment of children's hearing-studios, audio-video taping of

26. This course is entitled: Verdiepingsstage slachtofferzorg, see, Stichting Studiecentrum Rechtspleging 1999. Introductiepakket RAIO lichting 1999-III.

27. For magistrates, see: Magistrates' Association 1997. Victims and Witnesses Training Pack. 
examinations and video-linked questioning are elements of great sophistication.

The main advantage of children's hearing-studios is that the child is questioned by specially trained examiners. These studios are used in Belgium, Denmark, Iceland, Luxembourg, Norway, Sweden and the Netherlands (Brienen and Hoegen, 2000a: chapter 27'3). The child-friendly studio is divided into two parts, separated by a one-way or two-way screen. In one part, the child is questioned, in the other, a collegue examiner, a psychologist and the defence lawyer may observe the questioning. Usually, halfway through the questioning the examiner will step outside and speak to the persons on the other side of the screen, who may make suggestions. If the defence lawyer is present, which is recommended, fair trial requirements are met.

In Belgium and the Netherlands, this examination is recorded on audiovideo tape which shows the date and time of the hearing to allow for judicial control. The main advantage of taping is that the child-witness is only questioned once and does not have to be questioned again during the trial proceedings. ${ }^{28}$

In the common law jurisdictions however, this is not (yet) possible. The present rules of examination of witnesses demand live questioning and the possibility of cross-examination. As a result, England and Wales, Ireland and Scotland have opted for the questioning of vulnerable victim-witnesses via video-link. ${ }^{29}$ Victims are seated in a separate room away from the courtroom, and all contacts between them and those present in the courtroom go through a live television link. The preparations that must be made to make such an arrangement possible are considerable. Legislation must allow for the victim-witness to be absent from the courtroom at the time of his or her testimony, and it must settle issues of evidence such as who is allowed to question the victim through the link. Furthermore, expenses are considerable for high-quality cameras, microphones and television screens, as well as for furnishing a separate room. Despite these obstacles, questioning through a video-link is becoming more frequent.

To a large extent, these three reform measures are successful because they are not solely for the benefit of vulnerable victims, but also enhance

28. Belgium: Guideline on the Audiovisual Recording of Interrogations of Underaged Victims, 1999; the Netherlands: Dekens and Steen, 1997.

29. England: s. 23 Youth Justice and Criminal Evidence Bill 1998; Ireland: s. 13 of Part III of the Criminal Evidence Act, 1992; Scotland: personal communications, Victim Support Scotland. 
the quality of the criminal justice process as a whole. Victim-witnesses who could previously hardly cope with the strain of being questioned in open court, and were therefore poor witnesses, now have a better chance of getting their story across. The opportunities for arriving at the truth are therefore increased, and the quality of litigation improved. It is a major finding of our study that implementation of a measure that aims to improve the position of the victim is much more likely to succeed if the measure is also beneficial to others.

\section{Protection}

The principles of publicity, immediacy, and orality are found in all jurisdictions. This implies that in principle the proceedings in court should be open to the public and the testimonies should be given orally in the presence of all. In all jurisdictions, exceptions to these rules are allowed for various reasons. The most common exception to the principle of publicity is that legislation provides that part of the proceedings may be conducted in camera to protect the victim-witness from the public and the media. Factual success, therefore, entirely depends on the attitude of the judge towards such a provision, and the weight that is given to the principle of publicity. In most jurisdictions, if the court is faced with a request to hold a case behind closed doors it is usually inclined to respond positively after weighing the interests involved. Some jurisdictions have established a wider ranging policy. In Iceland, for instance, all cases involving sexual offences are automatically held behind closed doors, even though legislation provides that such a decision is at the discretion of the individual judge. ${ }^{30}$ Conversely, in Cyprus, Greece, Italy, Malta, Spain and Turkey, judges are (very) reluctant to close the court to the public, and requests for the trial to be held in camera are frequently turned down (Brienen and Hoegen, 2000a: chapter 27 ' 4).

Interestingly, attitudes toward a particular measure may also change in time. For example, in Norway from 1987 to 1991 all cases involving sexual offences were automatically held in camera, just like in Iceland, but this practice eventually evoked strong opposition, and now a trial is only held in camera if there are exceptional reasons to do so. ${ }^{31}$

Another factor related to the category of victims of sexual crime is that it is particularly traumatic for them to be (cross-) examined in open court

30. Personal communications, Rape Trauma Centre lawyer.

31. Personal communications with victim lawyer. 
about their past sexual history. In England, awareness of this problem had already surfaced in the mid-seventies (Sexual Offences (Amendment) Act 1976). Section 2 of this Act provided that in any rape trial "except with the leave of the judge, no evidence and no question in cross-examination shall be adduced or asked at the trial, by or on behalf of any defendant at the trial, about any sexual experience of a complainant with a person other than that defendant". Unfortunately, in practice judges almost invariably gave permission for the defence to question a female complainant about her past sexual history, and the provision had almost no practical effect. This was recognized in a recent government report, ${ }^{32}$ and stricter provisions have been proposed (ss. 40-42 of the Youth Justice and Criminal Evidence Bill 1998). Regarding factual implementation of legislation, this example shows that where there is disagreement among authorities about a provision, or where the interests of the victim must be weighed against those of the accused, a measure can only have practical effect for the benefit of the victim if it offers no easy escape clauses.

\section{Conclusions}

In most European jurisdictions, a consensus has emerged as to the general type of rights victims are entitled to within the framework of criminal justice. It is more problematic, though, to find out how the relevant legal provisions can be implemented effectively. To this end, we reported some of the main findings of empirical and comparative research in 22 member states of the Council of Europe.

Regarding the question of why certain reform measures fail while others succeed, the following conclusions may be drawn. First of all, implementation of legislation and guidelines has a much greater chance of succeeding if these measures are not exclusively for the benefit of the victim, but also serve a wider purpose such as enhancing the performance of the criminal justice process. This is demonstrated by the provisions for questioning victim-witnesses by means of child studios, audio-visual taping or video-links. Not only is the courtroom experience much less traumatic for the victim, but the quality of the testimony is improved. Secondly, the measures that are introduced should be clear and concise, leaving no room for debate on interpretation, and offering no easy escape

32. Speaking up for Justice, Report of the Interdepartmental Working Group on the Treatment of Vulnerable or Intimidated Witnesses in the Criminal Justice System, June 1998. 
clauses. Where the attitudes toward a measure are negative, escape clauses are readily made use of, as illustrated above in relation to compensation and the questioning of rape victims about their past sexual history. Thirdly, it is essential that no false starts be made with regard to implementation. Once there is an aura of failure around a measure, it is extremely difficult to shed this stigma. Finally, phased implementation in pilot areas deserves serious consideration but can only be effective if the results of the pilots are properly evaluated and the required adjustments made before progressing to nation-wide implementation.

The concept of a developmental scheme enables us to describe and analyze the ways in which progress in implementation issues is achieved. It facilitates our understanding of critical factors of success or failure, and the resulting knowledge can be used to shape strategies which actually benefit large numbers of victims throughout Europe.

\section{References}

BRIENEN, M.E.I. and HoEgEN, E.H. 1998. "Information Systems for Victims of Crime: Results of Comparative Research”, International Review of Victimology (5): 163-188.

BRIENEN, M.E.I. and HoEgEN, E.H. 1999. "Victims of Crime in Different Jurisdictions and the Influence of Local Realities", p. 157-164 in Caring for Victims: Selected Proceedings of the Ninth International Symposium on Victimology, J. van Dijk (ed.), Monsey, New York: Criminal Justice Press.

BRIENEN, M.E.I. and HOEGEN E.H. 2000a. Victims of Crime in 22 European Juridictions: The Implementation of Recommendation 85 (11) of the Council of Europe on the Position of the Victim in the Framework of Criminal Law and Procedure, Tilburg: Wolf Legal Productions.

BRIENEN, M.E.I. and HoEgen, E.H. 2000b (forthcoming). "Compensation Across Europe: A Quest for Best Practice", International Review of Victimology.

BRIENEN, M.E.I. and KOOPMANS, I.M. 1998. "Voeging en schadevergoedingsmaatregel: het slachtoffer blijft slachtoffer. Enkele kritische opmerkingen over de rechtspraktijk in het licht van de Wet Terwee", Nederlands Juristen Blad 30: 1345-1350.

B. \& A. GROEP 1998. Slachtofferzorg in Nederland. Eindrapportage. Den Haag.

CHerif BASSIOUNI, M. 1988. International Protection of Victims, 7 Nouvelles Études Pénales, Erès.

Claassens, J.C.A.M. and StOKer-Klein, B.A. 1995. "Het slachtoffer in het strafproces", Trema (6): 167-175.

DEKENS, K.M.K. and STEEN, J. van der 1997. Het kind als getuige: theorie en praktijk van het verboor, Den Haag: Vuga.

DIJK, J. van 1996. "Crime and Victim Surveys", p. 121-132 in International Victimology: Selected Papers from the 8th International Symposium, Chr. Sumner et al. (eds.). Canberra. 
Gabinete de Estudos e Planeamento do Ministério da JustiçA 1994. Inquérito de Victimação, Lisbon.

GonZÁLez GIL, P. et al. 1997. Estudios sobre la victima del delito (O.A.V.D. 19941996), Gobierno de Canarias.

GroenhuiJSEN, M.S. 1998. Objectives of Victim Assistance: the Professionalisation of Service Providing Organisations. A Comparison between European experiences and recent Developments in South Africa, Social Work Practice, Pretoria, South Africa: Department of Welfare.

GroenHUIJSEN, M.S. 1999. "Victims Rights in the Criminal Justice System: a Call for more Comprehensive Implementation Theory”, p. 85-144 in Caring for Victims: Selected Proceedings of the Ninth International Symposium on Victimology, J. van Dijk (ed.), Monsey, New York: Criminal Justice Press.

Joutsen, M. 1989. "Research on Victims and Criminal Policy in Europe", p. 5083 in Crime and Criminal Policy in Europe. Proceedings of a European Colloquium, Roger Hood (ed.). Oxford.

Joutsen, M. 1997. Criminal Policy and Victims of Crime: a European Perspective, Oxford.

Junger, M. and Van HeCKe, T. 1988. Schadevergoeding Binnen het Strafrecht, Den Haag: WODC.

Justitie departementet, Brottsoffer 1998. Vad har gjorts? Vad bör göras? SOU 1998, 40, Betänkande av Brottsofferutredningen. Stockholm: Justitie departementet.

KAISER, M. 1992. Die Stellung des Verletzten im Strafverfabren, Freiburg i. Br.

Kury, H., Kaiser, M. and TesKe, R. 1994. "The Position of the Victim in Criminal Procedure - Results of a German Study", International Review of Victimology (3): 69-81.

Lindgren, M. and Christianson, S.A. 1994. Relationen Mellan Polis och Brottsoffer i Stockholms Polismyndighet, PHS Rapport 1994: 2, Polishögskolan Forskningsheten December 1994, and personal communications with Victim Support Sweden.

Slotboom, A. and Wemmers, J. 1994. Tevree met Terwee? Samenvattende rapportage van de evaluatieonderzoeken, Den Haag: WODC.

VILMOW, B. 1985. "Implications of Research on Victimisation for Criminal and Social Policy”, p. 105-142 in Research on Victimisation, Reports presented to the sixteenth Criminological Research Conference. Strasbourg.

Walklate, S. 1989. Victimology. The Victim and the Criminal Justice Process, London.

WEMMERS, J. 1996. Victims in the Criminal Justice System, Amsterdam/New York: Kugler Publications. 